\title{
Infringements Liable to Protective Jurisdiction (Case Study: Islamic Republic of Iran, France and Egypt's Laws)
}

\author{
Mohammad Ali Khozeimeh, Majid Shayganfard \\ Department of Criminal Law and Criminology, Mashhad Branch, Islamic Azad University, Mashhad, Iran \\ Email: mkhozeimeh@yahoo.com
}

How to cite this paper: Khozeimeh, M. A., \& Shayganfard, M. (2017). Infringements Liable to Protective Jurisdiction (Case Study: Islamic Republic of Iran, France and Egypt's Laws). Beijing Law Review, 8, 311-320. https://doi.org/10.4236/blr.2017.83018

Received: July 3, 2017

Accepted: August 26, 2017

Published: August 29, 2017

Copyright (c) 2017 by authors and Scientific Research Publishing Inc. This work is licensed under the Creative Commons Attribution International License (CC BY 4.0).

http://creativecommons.org/licenses/by/4.0/ (c) (i) Open Access

\begin{abstract}
The international penal code of law is laid upon the territorial jurisdictions. However, countries try to extend the spatial domain of their penal laws to areas outside their sovereignty in several exceptional states meaning that in case a crime is perpetrated outside its jurisdiction a country knows its rules and courts as being qualified to try it. One such a case states that if a crime perpetrated abroad jeopardizes their essential and vital interests the type of the jurisdiction that is created under such a circumstance is called "protective jurisdiction". According to the nature and the intensity of the crimes dealt with based on the principle of protective jurisdiction, various countries do not accept any limitation and condition except the limitation of the examples of crimes subject to protective jurisdiction in regard of the international law for the execution of such an authority. The objective of the current research paper is the investigation of the crime examples subject to protective jurisdiction in the law of Iran, Egypt and France. The results obtained from the present analytical-descriptive study indicate that there are important crimes enumerated case-specifically among the crimes subject to protective jurisdiction in the statutory provisions exercised in countries like Iran, Egypt and France.
\end{abstract}

\section{Keywords}

Principle of Protective Jurisdiction, Spatial Territory of the Penal Law, The Principle of Territorial Jurisdiction

\section{Introduction}

In discussions on spatial territory of the penal law, the principle pivots about the territorial jurisdiction; the expansion of jurisdiction for the penal rules enforcement outside a territory is an exceptional case. In other words, the governments' 
territorial jurisdiction is restricted to their land, sea and air borders. Therefore, the enforcement of penal jurisdiction, to wit suing and penalizing the infringers, should not be extended to the offences that are perpetrated outside the borders of a country. Such a statement is an equivalent translation for the principle of territorial jurisdiction or better said the intra-border nature of the penal laws jurisdiction.

Since every country is seeking to preserve its stability and enforce its authority and sovereignty, such expediencies as protection of the system, occasionally, makes it necessary for the country to counteract any action that endangers its stability and persistence. So, what measures can be taken in case that the jeopardizing action is in progress outside the territorial jurisdiction of the country? It would be contradicting the principle of territorial jurisdiction if the domestic courts try the crime. Hence the principle of protective jurisdiction, as a special allocation and exception to the principle of penal laws' territoriality, came about in line with the expediencies of the system preservation.

Preservation of independence and adherence to the public expediencies come first in regard of crimes against the public security. Due to the same reason and for the importance and the high risk of crimes against the security, the states have to sometimes retract from the generally accepted penal rules. The principle of protective jurisdiction assists the states in such situations.

According to the criticality of the crimes specified under the title of protective jurisdiction, the countries do not envision any limitation and condition for its enforcement and, fortunately, in line with paying attention to this axiom and keeping the pace with the laws of the other countries, the legislator, in the new Islamic penal code of law, besides rejecting any restriction on enforcing this law, has somewhat expanded the interests supported by this axiom in contrast to the Islamic penal code of law enacted in 1991 and it has also taken into account the human rights considerations in exercising the punishments. To run a more thorough analysis on the protective jurisdiction, the current article takes a comparative look at the investigation of example crimes subject to protective jurisdiction.

\section{Theoretical Basics}

Before going on to the examples of crimes liable to protective jurisdiction in the laws of Iran, Egypt and France, it is necessary to firstly deal with a study of theoretical framework.

\subsection{The Importance and Definition of Protective Jurisdiction}

\subsubsection{Defining the Principle of Protective Jurisdiction}

The principle of protective jurisdiction means developing legislative and judicial jurisdictions of a sovereign state to the crimes that are committed outside the country's territory and threaten the essential and vital interests thereof ${ }^{1}$.

${ }^{1}$ Poorbafrani (2011), “international criminal law", $3^{\text {rd }}$ ed., Tehran, Jungle Publication, p. 121. 
In this principle, the sole scale and foundation of creating jurisdiction and authority is the nature and the intensity of the crime perpetrated against the essential and vital interests of the country exercising such a jurisdiction. To put it differently, according to the dangers that the countries feel about the occurrence of such crimes, they yield to accepting such a jurisdiction. This idea of protecting and preserving the society's interests has caused the aforementioned principle to be also termed defensive juridiction ${ }^{2}$.

\subsubsection{The Importance of Protective Jurisdiction}

It is seen through scrutinizing the criminal law history that the most fundamental principle in the arena of international criminal law has always been the principle of territorial jurisdiction; this principle per se incorporates three sovereignty aspects of legislative jurisdiction (the right to enact and approve rules), judicial jurisdiction (the right to interpret and exercise rules) and the executive jurisdiction (the right to exercise rules and orders issued by the courts) ${ }^{3}$. In the meantime, the unique features of the principle of territorial jurisdiction ${ }^{4}$ did not make the governments disarmed against the crimes that were carried out outside their territories and endangered their security. Quite inversely, the history of criminal law indicates that various countries have always been reacting to the crimes that were deemed perilous to their essential and vital interests even if they were committed outside their territorial sovereignty and by the foreigners ${ }^{5}$.

In fact, under such circumstances, the perpetration of crimes is accompanied by harmful effects for a country and as interpreted by some professors the penal reaction that is adopted by a country in regard of such harms is to be termed legitimate defense and the state suffering the harm cannot leave its defense to the other countries in such cases ${ }^{6}$.

Garu, a French jurist, has a special rendering in this regard: "in fact, the sovereign state is the victim and harmed party to such crimes and it can per se take measures to sue the perpetrators and it does not differ whether such crimes are committed inside or outside a country"7.

It is based on such thoughts that the principle of protective jurisdiction has come to existence in protection of the foresaid essential and vital interests.

Such a type of jurisdiction is important to the countries to the extent that even in case that their own citizens perpetrate them outside their territories, the jurisdicational principle that can be enforced is not the personal jurisdiction principle but the protective jurisdiction. It is evident that the conditions and the restrictions that inhibit the enforcement of personal jurisdiction in the interna-

${ }^{2}$ Khaleghi (2009). “exploration in international criminal law”, Tehran, Shahr-e-Danesh, p. 43 and Mir Mohammad Sadeghi (1998), "International criminal law (collection of articles)", Tehran, Mizan, p. 28.

${ }^{3}$ Kittichaisaree (2005) International Criminal Law, Third Edition, Oxford, 2005, p. 38.

${ }^{4}$ Cassese (2008) International Criminal Law, Second Edition, Oxford, 2008, p. 336.

${ }^{5}$ Hosseininejad (1994), “international criminal law”, $1^{\text {st }}$ ed., Tehran, Mizan, p. 57.

${ }^{6}$ Ali Abadi (1991) “Criminal Law”, v.3, Tehran, Ferdowsi, p. 142.

${ }^{7}$ Garraud (1964), "theoretical and practical research on the penal codes of law", v.1, tr. Sayyed Zia'a Al-Din Neghabat, Ebn-e-Sina, p. 342. 
tional penal laws and by the various countries are nonexistent for the principle of protective jurisdiction. For instance, different countries suspend the exertion of personal jurisdiction on the presence of certain conditions including the perpetrated crimes' degrees of importance, mutual criminality, the lack of a prior trial and the culprit's return to the country against which the crimes are com$\mathrm{mitted}^{8}$, but none of these foresaid cases are observed in regard of the principle of protective or defensive jurisdiction.

\subsection{The Characteristics of Protective Jurisdiction}

There are conditions and limitations in exercising the other principles of the criminal rules jurisdiction outside the sovereignty of a country (the principle of personality jurisdiction, the principle of jurisdiction based on the victim's citizenship and the principle of universal jurisdiction) that consider the importance of the perpetrated crime, mutual criminality (the criminality of the action both in the country where it has happened and in the country exercising its jurisdiction right), the crime's being tried for the first time and the presence of the convict whereas none of the abovementioned conditions and limitations exist for the exertion of this principle. This is due to the specific nature of the crimes subject to this principle because they are generally the crimes that directly target the essential and vital interests of a country including the political, territorial and economical integrity of the governments. In other words, the entire crimes that are somehow considered as damaging the domestic and foreign security as well as the public welfare of a country are considered as important cimes so the condition of importance resides in all of them and there is no need for it to be explicitly mentioned.

On the other hand, these are only considered as crimes concerning the involved countries and they are not specified as even offensive acts in the other countries' rules for example the crimes against Iran's internal and external security are crimes only based on Iran's regulations and the other states do not realize them that way. Quite similarly, the crimes against the internal and external security of France are exclusively considered as crimes based on the law of France and they are not deemed as crimes in the law of Iran or the other countries.

Thus, if the mutual criminality has to be decided by all the countries, no court would have the qualification for trying these crimes against the internal and external security of a country and, evidently, taking such a condition into consideration means drawing a line of vanity over the principle of protective jurisdiction.

Based on this, the condition "the crime's not being previously tried" also cannot be actualized because, first of all, as it was mentioned, the other countries' rules do not take as a crime the infrigenements against the security of the countries other than themselves let alone the trial by the qualified courts ${ }^{9}$ and, secondly, assuming an action as a crime under certain exceptional conditions, sim-

${ }^{8}$ Poorbafrani (2011), Ibid, p. 59.

${ }^{9}$ Ryngaert (2008) Jurisdiction in International Law, Oxford, 2008, p. 96. 
ilar to what has happened in the article 502 of Iran's Islamic penal code of law ${ }^{10}$, the trial of such crimes by the courts of another country is a high hope that is far from coming true thus accepting the condition "the crime's not being priorlly tried in another court" within the jurisdiction of the country wherein the crime has occurred is a sort of contradictory idea and seems illogical.

Accordingly, various countries have not opined it necessary for the criminal to be present in the country exercising the jurisdiction and they believe in trying such criminals even in their absence. For specimen, France, despite its adherence to conditions such as the criminal's apprehension and extradition to France's state for trial in its previous rulings, in the article 113-10 of the penal law, passed in 1992, dismisses the condition as a result of which trying these criminals in absentia has been made possible.

In article 19 of the Lebanon's penal code of law, the presence of a foreign criminal or another country's citizen in Lebanon or his or her apprehension are not stipulated as preconditions and trying the criminal in absentia is envisaged as correct based on the law ${ }^{11}$. Trial in absentia has also been made permissible based on the second paragraph of the article 2 of Egypt's penal law ${ }^{12}$. It is clear that believing in the permissibility of trial in absentia of the crimes subject to the protective jurisdiction is more consistent with the basic principles of the protective jurisdiction because such a statutory provision has been stipulated in line with defending the essential and vital interest of the countries and giving room for the aforementioned constraint makes the protective jurisdiction deprived of its necessary efficiency. Additionally, a great many of the crimes subject to this principle, due to their direct contrast to the sovereignty, are enumerated as political crimes and the countries, corresponding to an old and accepted axiom, are practically prohibited from extradicting the political criminals.

Thus, it is difficult, in practice, to put hand on such criminals. Now, if trial in absentia was not possible, the criminals could become more arrogant in committing crimes and the countries' security would be jeopardized resultantly; while, now that it is possible to adjudicate and convict such criminals, the same ruling in absentia can socially restrain them and it is possible to arrest and inflict them with punishments through such legal tools as international police and so forth.

\section{Crimes Liable to Protective Jurisdiction in the Laws of Iran, Egypt and France}

\subsection{Crimes Liable to Protective Jurisdiction in Iran's Law}

Article 5 of the Islamic Penal Code of Law, approved in 2013, states that: every

\footnotetext{
${ }^{10}$ Based on this article: "whoever who commits any sort of espionage crimes in the territory of Iran in favor of a foreign country and against another country in such a manner that such an infringement is found harming the national security s/he will be sentenced to imprisonment from 1 to 5 years.

${ }^{11}$ Al-Zzoghbi (1995), "Al-Mowsu'at Al-Jaza'eeiyya”, v.6, p.163, Sader.

${ }^{12}$ Abdulmalek (2008) “Al-Mowsu'at Al-Jaza'eeiyya”, v.5, p.607, Dar Al-Ehya'a Al-Torath Al-Arabi; Mahmoud Ebrahim (1959), "Sharh Al-Ahkam Al-Amma fi Ghanoon Al-Oghubat”, p.201, Dar Al-Fikr Al-Arabi.
} 
Iranian or any non-Iranian who perpetrates one of the following crimes stipulated by special statutory provisions outside Iran's sovereignty will be punished corresponding to the regulations of the Islamic Republic of Iran's regulations and whenever trying such crimes outside Iran leads to the issuance and enforcement of a conviction, Iran's court is responsible for determining and calculating the punishment based on its canonical scale of Ta'azir.

a) Perpetrating a crime against the government, internal or external security, territorial integrity or the independence of Islamic Republic of Iran.

b) Forging and/or misusing the seal, signature, ruling, commandment or handwriting of the supreme leader.

c) Forging and/or misusing the seal, signature, ruling, commandment or formal handwriting of the president, the head of judicature, the head and representatives of the parliament, the head of the council of leadership experts, the head of the country's supreme court, the country's solicitor general, members of guardians council, the head and members of expediency discernment council of the system, ministers or the vice deputies.

d) Forging and/or misusing the rulings by the judicial courts or the official writs issued by the courts or the other legal sources.

e) Forging currency bills or the other binding documents issued by Iran's banks as well as forging the treasury documents and the participation bonds issued or warranted by the government or procurement and promotion of forged coins.

Thus, the legislator, adhering to the rules of just and fair trial, accepts the axiom of calculating and inflicting punishments in foreign countries' courts within the realm of Ta'azir punishments in the foresaid article. Although the legislator has not explicitly asserted the prohibition of retrial like the majority of the other countries in regard of the protective jurisdiction, it has not denied and refuted the prior trial of the convict with its approval of punishment calculation; however, according to the insignificance of suing, trying and punishing some of the crimes subject to this article for the courts of the other countries, there is probably not left so many cases for the exertion of this section of article but its insertion in the article as an indicator of the legislator's concern for the observation of the convicts' rights and preventing any injustice and cruelty against them and simultaneously his human right considerations is a positive and favorable measure.

Also, the legislator has added the paragraph 4 that presents the rulings on "forging and/or misusing the verdicts by the judicial courts or the official writs issued by these courts as well as the other legal sources" to the interests collection supported in this article. Since the government of Iran has signed various judicial assistance, convicts extradition, convicts imprisonment and rogatory commission agreements with the other countries and there is the probability of the judicial courts to be exposed to forgery offences by the criminals, this latter stipulation can be of a great help. Also, in its paragraph 3, the article mentions 
forging and/or misusing the seal, signature, commandment, verdict or the formal handwriting and so forth of the head and members of expediency discernment council of the system. Generally, it is observed through scrutinizing the interests supported in this article that the public security and welfare is continuously backed up and the crimes against security and the important crimes against the public welfare which are predominantly considered under the title of the crime of forging documents and coins constitute the major crimes dealt with in the protective jurisdiction.

\subsection{Crimes Liable to Protective Jurisdiction in France's Law}

France's penal law, approved in 1992, in article 113-10 states that "as for the crimes and infringements that are perpetrated against the essential national interests (the nation's underlying interests) for which the first title of the fourth book of this law specifies punishments as well as regarding forgery and duplicity and fabricating the governmental seals, money, coins, bills or securities for which articles 442-1, 443-1 and 441-1 specify the punishments and also regarding the entire crimes and infringements which are committed against France's political agents or places or consulates outside the territorial sovereignty of France, the penal code of choice will be that of France's".

Utilizing scrutiny in this article, it can be said that the interests supported by the legislator include three sets: first of them incorporates the crimes and violations against the national essential interests (or the underlying interests of the nation) and the punishments of them have been determined in the first title of the fourth book on France's penal law. These crimes can be called infringements against the domestic or foreign security ${ }^{13}$.

Through close examination of the first title of the fourth book on France's penal law, it can be understood that articles 410-1 to 414-9 of France's penal law specify these essential interests ${ }^{14}$.

The first title of the fourth book includes topics on "abuses to the essential national interests". This title, per se, embraces four chapters. The titles of the chapters and their subsections are as stated below:

Chapter One: in traison and espionage. It includes six discussions: 1) the submission of a part or the entire national territory, military forces, equipment and tools to a foreign government; 2) providing assistance to a foreign state; 3 ) submitting the information to a foreign state; 4) sabotage; 5) procuring fake information; 6) stimulating to perpetrate predicted crimes in this chapter.

Chapter Two: the other abuses to to the republican institutions or the national territorial integrity. The chapter includes three topics: 1) attempt on life and conspiracy; 2) rebellious movements; 3) usurping commandership, recruiting military forces and provoking to illegal arming

Chapter Three: other breaches of the national defence. This chapter encom-

${ }^{13}$ Desportes \& Le Gunehec (1996) Le Novean Droit Penal, Économico.1996, p. 304.

${ }^{14}$ Stefani, Levassor, \& Bouloc (1995) Droit Penal General, Dalloz.1995, p. 154. 
passes two topics: 1) abuses to the security of the military forces and the regions that are protected for national defense reasons; 2) Breaches of the national defense secrets.

Chapter Four: special cases. This chapter does not contain separate discussions and topics and 9 Articles are handled under the title of this chapter, namely 414-1 to 414-9.

The second set: forging and duplicity and making fake copies of the government seals, coins, currency bills or securities for which punishments have been specified in Articles 442-1, 443-1 and 441-1. These crimes are considered crimes against public welfare but not all of the crimes therein are against the public welfare. Using scrutiny in the cases pointed out herein it becomes clear that article 444-1 pertains to the crime of forging money bills or bank transfer bills. Article 443-1 is connected to forging the bills issued by the general treasury office or issued by the foreign governments and the article 444-1 deals with governmental seals and stamps.

The Third Set: it is the set of the interests that are to be under the protection of the France's government and the authority of the regulations and the jurisdiction of the penal courts have been extended to the areas out of the scope of the sovereignty of France. It incorporates the entire crimes and infringements that are committed outside France against the France's agents or political places or consulates.

As it is observed, the French legislator knows its regulations and courts qualified for whatever it considers as its essential interests even thought the crime against these interests are perpetrated outside its sovereignty and by the foreigners. This is called protective jurisdiction in the international criminal law. As it is opined by the French jurists regarding this principle, "neither the citizenship of the victim of crime and the criminal nor the place where the crime has taken place is important; rather, the nature of the crime is the criterion of scale. So, the law of France is applicable to the crimes that are against its expediencies and essential interests. ${ }^{15}$ "

Based on this, first of all, it is clearly understandable from the article 113-10 that the idea put forth in this statutoty provision is the nature of the committed crime which is against the superior interests of the France thus it does not differ whether the crime is perpetrated by a foreigner or a citizen. Therefore, if such crimes are committed by the French citizens outside France the same rule should be exercised.

\subsection{Crimes Liable to the Protective Jurisdiction in Egypt's Law}

Paragraph 2 of the Article 2 in Egypt's penal code of law explicitly names the crimes against the security of the government (crimes against domestic and foreign security) as well as the crime of forgery and duplicity ${ }^{16}$.

${ }^{15}$ Desportes, Ibid, p. 287.

${ }^{16}$ Mahmoud Ebrahim (1959), Ibid, p. 201 
In the enactments of this country, there are stipulated statutory provisions regarding the crimes against security and the infringements to the public welfare such as forging the securities and bank documents. Examining the regulations makes it clear that various countries consider whatever they call crimes against their domestic and foreign security conflicting their essential and vital interests; additionally, in the area of crimes against public welfare these countries posit crimes such as fabricating coins and forgery, especially forging the bank documents and papers, government stamps and passports as belonging to this field.

\section{Conclusion}

The crimes can be approached from two perspectives in every country. One is approaching the crime from the perspective of the country in which it is perpetrated and the other is approaching the crime from the perspective of the other countries. From the place of perpetration point of view, the crime is envisaged as damaging the public order and thus the courts therein try the crime based on the territorial jurisdiction in order to restore public order; including those cases where the crime has been perpetrated by the citizens of that country or by the citizens of the other countries. But from the perspective of the other countries, the crime committed is not a matter of protection and their courts are not qualified to try such crimes. That is because, based on the common principles, the crime committed in the other countries has not meant harm to their public order and it has had nothing to do with them. Therefore, the primary principle here is that the regulations commonly employed by the courts of a country for trying the crime perpetrated in another country are not suitable enough. However, in certain cases, various countries consider their regulations and courts qualified for trying the crimes perpetrated outside their jurisdiction and sovereignty. These cases are: 1) when the citizens of these countries commit a crime outside their sovereignty and jurisdiction (the principle of personality or nationality jurisdiction); 2) when their citizens become the victims of crime outside their sovereignty (the principle of jurisdiction based on the citizenship of the victim of crime); 3) when the crime is found against these countries' essential and vital interests, disregarding the citizenship of the perpetrator (the principle of protective jurisdiction) and 4) when the crime is seen as being outside the scope of the international crimes (the principle of universal jurisdiction). The current research paper dealt with the survey of the third exception; that is to say where the various countries get involved in developing the spatial territory of their criminal law when it is their essential and vital interests that are on the line outside their territorial jurisdiction.

The topics that are subjected to this very principle under the title of essential and vital interests are the countries' securities and their public welfare. In more precise terms, whatever that means any sort of harm to the countries' security (crimes against security) is the subject of protective jurisdiction. Similarly, some of the most important examples of crimes against the public welfare (such as 
forging currency bills and fabrication of fake coins) are also subjects of this principle.

Due to the scarcity of Persian literature, even the Arabic and French ones, pertaining to the laws of Egypt and France, it was attempted in the current research paper to compare and evaluate the examples showcasing the crimes subject to Iran, Egypt and France's protective jurisdiction. It is hoped that the current research paper has been successful in doing so.

\section{References}

Abdulmalek, J. (2008). Al-Mowsu'at Al-Jaza'eeiyya. Vol. 5, Dar Al-Ehya'a Al-Torath Al-Arabi, 1441.

Ali Abadi, A. H. (1991). Criminal Law (2 ${ }^{\text {nd }}$ ed.). Vol. 3, Tehran: Ferdowsi.

Al-Zzoghbi, F. (1995). Al-Mowsu’at Al-Jaza’eeiyya. Vol. 6, Sader.

Cassese, A. (2008). International Criminal Law(2nd ed.). Oxford.

Desportes, F., \& Le Gunehec, F. (1996). Le Novean Droit Penal, Économico.

Garraud, R. (1964). Theoretical and Practical Studies in Criminal Law. tr. Sayyed Ziya'a Al-DdinNeghabat, Vol. 1, Ibn-e-Sina.

Hosseininejad, H. G. (1994). International Criminal Law (p. 57). Tehran: Mizan.

Khaleghi, A. (2009). Quarries in International Criminal Law. Tehran: Shahr-e-Danesh.

Kittichaisaree, K. (2005). International Criminal Law(3rd ed.). Oxford.

Mahmoud Ebrahim, E. (1959). Sharh Al-Ahkam Al-Amma fi Ghanoon Al-Oghubat. Dar Al-Fikr Al-Arabi.

Mir Mohammad Sadeghi, H. (1998). International Criminal Law (Collection of Articles). Tehran: Mizan.

Poorbafrani, H. (2011). International Criminal Law (3 $3^{\text {rd }}$ ed., p. 121). Tehran: Jungle Publication.

Ryngaert, C. (2008). Jurisdiction in International Law. Oxford. https://doi.org/10.1093/acprof:oso/9780199544714.001.0001

Stefani, G., Levassor, G., \& Bouloc, B. (1995). Droit Penal General, Dalloz.

Scientific Research Publishing

Submit or recommend next manuscript to SCIRP and we will provide best service for you:

Accepting pre-submission inquiries through Email, Facebook, LinkedIn, Twitter, etc. A wide selection of journals (inclusive of 9 subjects, more than 200 journals)

Providing 24-hour high-quality service

User-friendly online submission system

Fair and swift peer-review system

Efficient typesetting and proofreading procedure

Display of the result of downloads and visits, as well as the number of cited articles

Maximum dissemination of your research work

Submit your manuscript at: http://papersubmission.scirp.org/

Or contact blr@scirp.org 